\title{
The Carolina kimberlite, Brazil - insights into an unconventional diamond deposit
}

\author{
Lucy Hunt ${ }^{1}$, Thomas Stachel ${ }^{1}$, Roger Morton ${ }^{1,2}$ and Herman Grütter ${ }^{3}$ \\ ${ }^{1}$ Department of Earth and Atmospheric Sciences, University of Alberta, Edmonton, AB, Canada T6G 2E3, \\ ${ }^{2}$ Sola Resource Corp, 120-3442 118th Ave. SE, Calgary, AB, Canada, T2Z $3 X 1$ \\ ${ }^{3}$ BHP Billiton World Exploration Inc, \#800 Four Bentall, 1055 Dunsmuir Street, Vancouver, B.C. V7X 1L2, Canada
}

\section{Introduction}

Diamond exploration has long been guided by "Clifford's rule" (Clifford, 1966) which states that diamondiferous kimberlites are restricted to areas that have been stable for at least $2 \mathrm{Ga}$. This rule was later adapted by Janse (1994) who stated that primary diamond deposits are restricted to Archons (Archean aged cratons). Clifford's rule has recently been challenged through the discovery of diamondiferous kimberlites in the Pimenta Bueno area of Brazil located on a terrane $<2 \mathrm{Ga}$ in age. We have studied diamonds and mantle xenocrysts from the Carolina kimberlite in the Pimenta Bueno area to determine if this unconventional setting is associated with unusual geochemical signatures.

\section{Geological Background}

The Carolina kimberlite is located in the southeastern portion of the state of Rondônia, Brazil. Here alluvial diamond deposits have been mined from the Pimenta Bueno and Comemoração rivers since the 1930s. Exploration for the primary source of these diamonds began in 1974 and the Carolina Kimberlite itself was found in 2002 .

The South American platform of Brazil is underlain by an assemblage of two cratons, the Amazon craton and the São Francisco craton. The Rondônia kimberlite province, including the Carolina pipe, is located on the Amazon craton (Fig. 1) within basement rocks of Proterozoic age (1.8 to $1.2 \mathrm{Ga}$ ). The ages of these crustal rocks have been tightly constrained by a number of studies (Tohver et al., 2005 and references therein). Little work has been carried out to confirm the Proterozoic age of the underlying lithospheric mantle.

Thirty two kimberlites occur to the east of the Carolina property and are thought to be of two distinct ages, namely: Carboniferous ( 360-300 Ma) and CretaceousTertiary (Zurowski, 2003). For the Carolina kimberlite itself we determined emplacement at $232 \mathrm{Ma} \mathrm{(+/-}$ 2.3Ma; phlogopite $\mathrm{Rb} / \mathrm{Sr}$ model age).

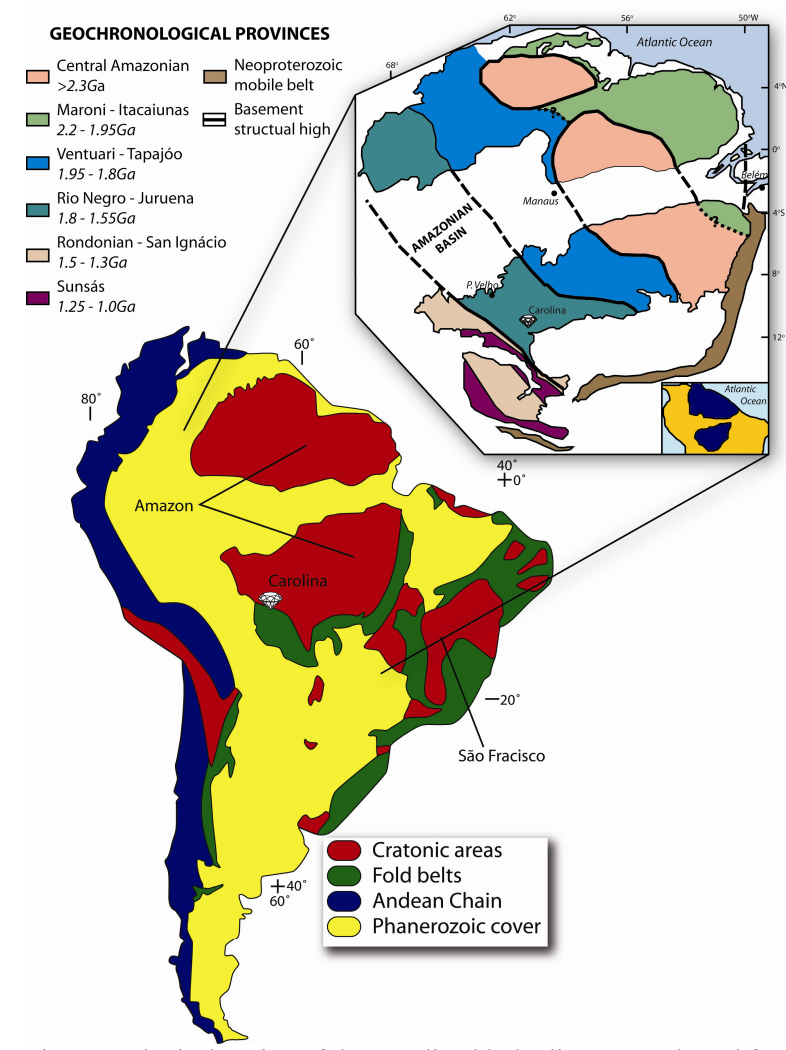

Fig. 1 Geological setting of the Carolina kimberlite. Inset adapted from (Tassinari and Macambira, 1999)

\section{Diamonds}

So far, 158 diamonds from the Carolina kimberlite have been analyzed for their nitrogen characteristics. For a subset of 30 diamonds, ranging from 3.0 to $31.7 \mathrm{mg}$, colour and morphological properties have been documented in detail and for 26 of these samples carbon isotopic data have been obtained. The diamonds were recovered during bulk sampling of the kimberlite.

Morphology: Morphological analyses showed the diamonds to be predominantly rounded $(32 \%)$ or irregular (partially broken) (26\%) dodecahedra. A further $26 \%$ classify as irregular crystals with no discernable morphology. The remaining stones are octahedra (12\%) and macles (4\%).

Colour: The 30 diamonds described in detail are dominated by grey, partially coated crystals (48\%), 
followed by colourless $(23 \%)$, yellow $(16 \%)$, brown $(10 \%)$, and pink $(3 \%)$ diamonds. Typically, brown and pink colouration relates to plastic deformation creating defects in the diamond lattice (Harris, 1987). Surface features indicative of plastic deformation, such as deformation lines on dodecahedral faces are, however, lacking in the majority of cases. Yellow colour is caused by nitrogen impurities substituting as N3 centres in the diamond crystals (Harris, 1987).

Surface Features: Surface features are associated with the diamonds morphology, with certain features restricted to dodecahedral faces, and others seen on octahedral faces only. As a consequence of the abundance of dodecahedral stones in the sample set, features restricted to these faces dominate. These included terraces and hillocks of varying forms created by the resorption of primary octahedral growth layers. Ruts and corrosion scultpture were noted on highly resorped faces.

Carbon Isotopic Composition: Carolina diamonds show a range in carbon isotopic composition from -22.4 to $-3.7 \%$, with $2 / 3$ of the samples having a mantle like carbon isotopic signature $\left(\delta^{13} \mathrm{C}\right.$ near $\left.-5.5 \%\right)$. Worldwide, peridotitic diamonds show a narrow range in $\delta^{13} \mathrm{C}$ (about -10 to $-2 \%$ o), whilst eclogitic diamonds have isotopic compositions that may extend to very negative ( $-38 \%$ ) values (Cartigny, 2005; Kirkley et al., 1991). Based on these worldwide relationships it appears likely that at least the more negative isotopic values observed for some Carolina diamonds indicate derivation from eclogitic mantle sources. Correlations between carbon isotopic composition and diamond morphology/colour were not observed.

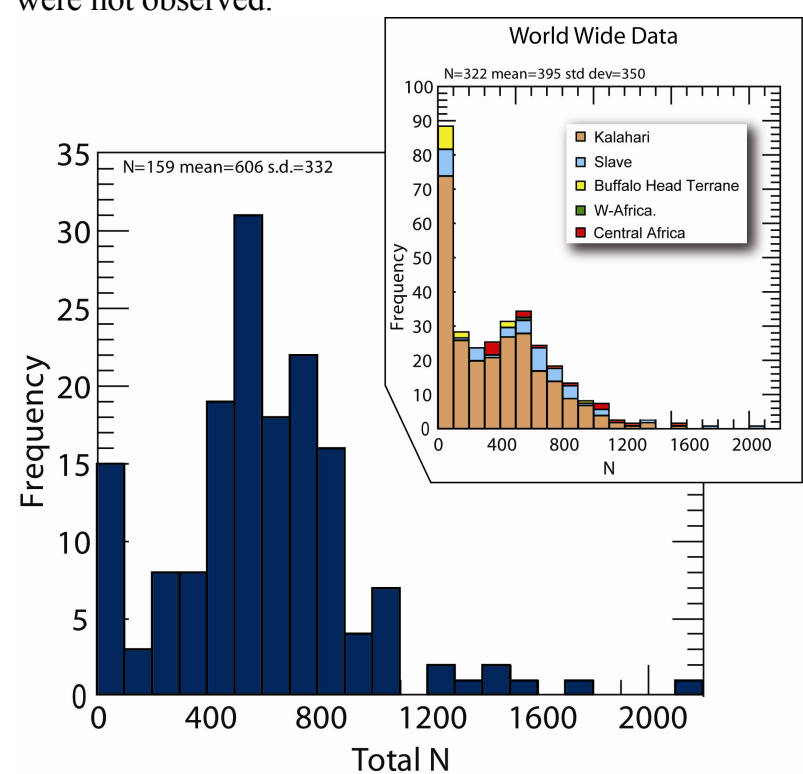

Fig. 2. Nitrogen histogram of the Carolina diamonds. Insert shows worldwide nitrogen contents for diamonds with eclogitic inclusions. Based on nitrogen contents, eclogitic diamonds from world wide sources (overall higher total nitrogen than peridotitic diamonds), appears to be good match for Carolina diamonds.

Nitrogen Content and Aggregation State: All the diamonds from the Carolina pipe contain measurable nitrogen and are classified as Type I. Nitrogen concentrations range from 19 to 2124 atomic ppm.
Worldwide, diamonds without detectable nitrogen (Type II) comprise $\sim 30 \%$ of all samples $<0.02$ carat $(<0.02$ carat, Cartigny, 2005). The lack of Type II diamonds at Carolina is, therefore, considered unusual. Overall high nitrogen contents (average: 600 atomic ppm) are a further indication of a strong eclogitic contribution to the Carolina diamond population (see Fig. 2).

Diamonds can be sub-divided based on the aggregation state of their nitrogen impurities (Evans et al., 1981). Type Ib diamonds contain nitrogen mainly in its unaggregated form (single substitutional $\mathrm{N}$ ), Type IaA contain $>90 \%$ of nitrogen as pairs and Type IaB diamonds have $>90 \%$ of their nitrogen in the highest aggregation state, as groups of four N. Type IaAB diamonds represent an intermediate state. Aggregation of nitrogen occurs during mantle residence and depends on both total nitrogen content and temperature. At mantle temperatures the transition from Type Ib to IaA occurs very rapidly whilst aggregation from Type IaA to $\mathrm{IaB}$ generally takes hundreds of millions to billions of years. Eighty-nine percent of the Carolina diamonds classify as Type IaAB, indicating intermediate aggregation states. This is common amongst diamonds from other localities (Stachel, 2007).

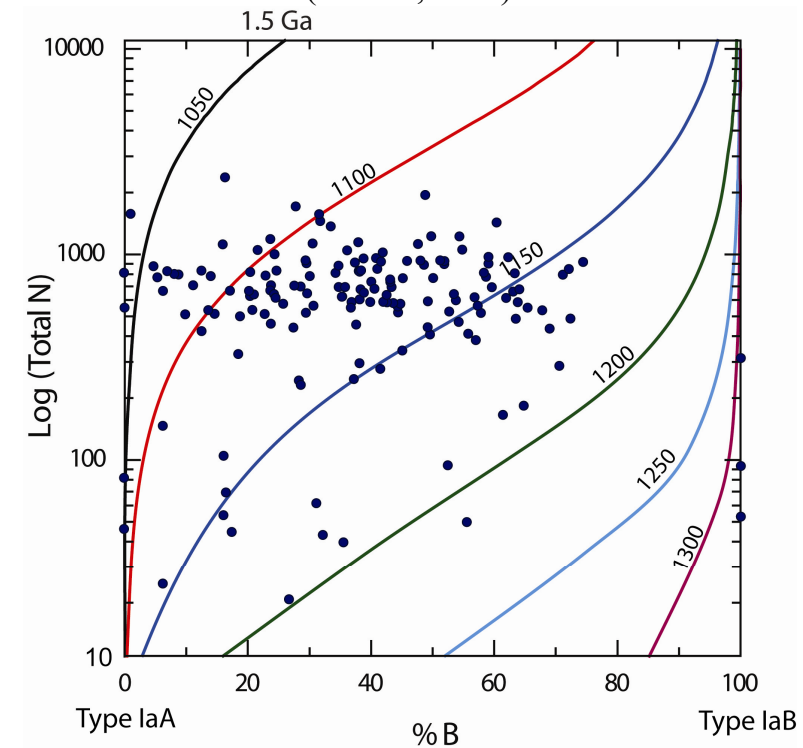

Fig. 3. Time averaged mantle residence temeratures deermined from nitrogen content and aggregation state. Isotherms based on a $1.5 \mathrm{Ga}$ mantle residence time are calculated after Taylor et al., 1990 (calculated from Leahy and Taylor, 1997; Taylor et al., 1990)

Time averaged mantle residence temperatures can be determined for an assumed mantle residence time using the aggregation state (relative proportion of nitrogen in the B-centre) and concentration of nitrogen (calculated from Leahy and Taylor, 1997; Taylor et al., 1990). Calculated for a mantle residence of $1.5 \mathrm{Ga}$, the majority of Carolina diamonds indicate residence temperatures between $1100-1150^{\circ} \mathrm{C}$ (Fig. 3).

\section{Garnet Xenocrysts}

Garnet xenocrysts in concentrate from drill core $(n=66)$ and surficial samples $(\mathrm{n}=308)$ predominantly derives from peridotitic sources $(87 \%)$ which are exclusively lherzolitic (G9) in paragenesis. The absence of 
harzburgitic (G10) garnets is unusual for a diamondiferous kimberlite but consistent with the postArchean setting (c.f. Griffin et al., 1999; Hood and McCandless, 2003).

A small proportion (13\%) of the garnets are eclogitic in composition. Just over half the eclogitic garnets classify as Group I $\left(>0.07 \mathrm{wt} \% \mathrm{Na}_{2} \mathrm{O}\right.$, McCandless and Gurney, 1989), which is considered as an indication of good diamond potential. In addition to the occurrence of highly negative carbon isotopic values and overall high nitrogen contents, this may indicate that Carolina diamonds are sourced in eclogite.

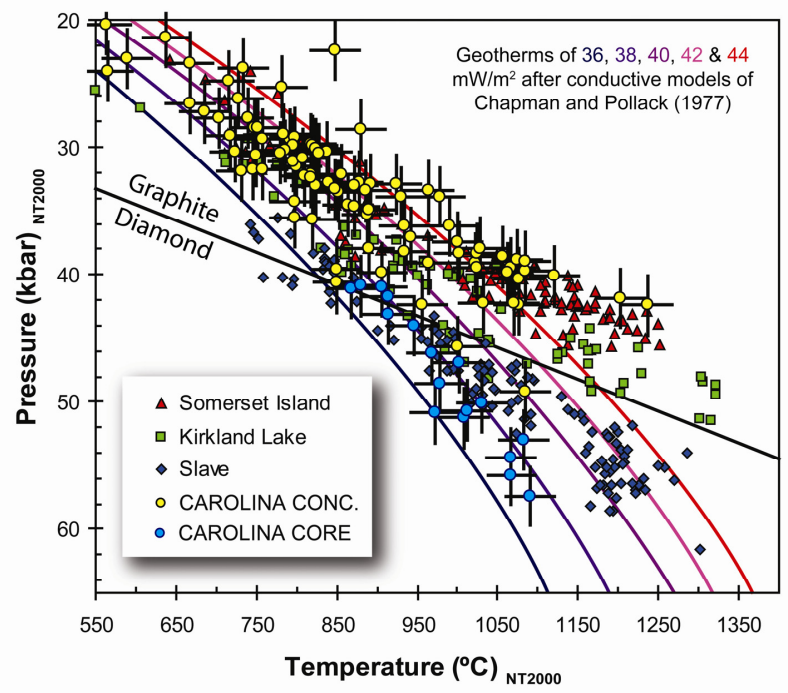

Fig 4. P-T estimates based on the clinopyroxene thermonbarometer of Nimis and Taylor (2000). Data from the Slave Craton, Kirkland Lake and Somerset Island are shown for reference to indicate low, intermediate and high cratonic geotherms.

\section{Clinopyroxene Xenocrysts}

All but 4 of 129 clinopyroxene xenocrysts recovered from surficial samples and drill core fall within the 'oncraton' garnet peridotite field in the $\mathrm{Cr}_{2} \mathrm{O}_{3} / \mathrm{Al}_{2} \mathrm{O}_{3}$ discrimination diagram of Ramsay (1992). For clinopyroxene from garnet peridotites, P-T conditions of last equilibration may be estimated (Fig. 4) using the single crystal geothermobarometer of Nimis and Taylor (2000). The clinopyroxene grains reflect two distinct geotherms: a hot "Somerset Island type" geotherm $(44 \mathrm{~mW} / \mathrm{m} 2)$ predominates in cpx from surficial samples, while a colder "Slave type" geotherm $(38 \mathrm{~mW} / \mathrm{m} 2)$ is defined exclusively by cpx from the Carolina kimberlite core samples. This implies that at surface clinopyroxene from volcanic sources associated with a higher geothermal gradient are mixed with material derived from Carolina itself. Given the Triassic age of the Carolina kimberlite, the younger generation of Cretaceous-Tertiary kimberlites in the Pimenta Bueno area likely represent the second source of mantle xenocrysts. This implies that in the time span between the Triassic and the Cretaceous heating of lithospheric mantle beneath the southeastern Amazon Craton occurred. Similar observations have previously been made e.g. for the Sao Francisco Craton, where thermal erosion of the deep mantle lithosphere occurred in a time window between 95-85 Ma (Read et al., 2004).

\section{Conclusions}

A typical cratonic model geotherm $\left(\sim 38 \mathrm{~mW} / \mathrm{m}^{2}\right.$ surface heat flow) is implied by clinopyroxene derived directly from the Triassic Carolina kimberlite. Concentrate is void of harzburgitic (G10) garnets but contains a significant proportion of eclogitic garnets with prospective $\left(\mathrm{Na}_{2} \mathrm{O}>0.7 \mathrm{wt} \%\right)$ mineral chemistry. Combined with overall high nitrogen in diamonds and the presence of highly ${ }^{13} \mathrm{C}$ depleted carbon isotopic compositions, derivation of Carolina diamonds from predominantly eclogitic sources is indicated. Nitrogen thermometry (based on $1.5 \mathrm{Ga}$ mantle residence) shows that the majority of Carolina diamonds resided at temperatures of $\sim 1100-1150{ }^{\circ} \mathrm{C}$, which compares well with cratonic diamond occurrences world wide.

\section{References}

Cartigny, P., 2005. Stable isotopes and the origin of diamond. Elements, 1(2): 79-84.

Chapman, D.S. and Pollack, H.N., 1977. Regional geotherms and lithospheric thickness. Geology, 5(5): 265-268.

Clifford, T.N., 1966. Tectono-metallogenic units and metallogenic provinces of Africa. Earth and Planetary Science Letters, 1(6): 421434.

Evans, T., Qi, Z. and Maguire, J., 1981. The Stages of Nitrogen Aggregation in Diamond. Journal of Physics C-Solid State Physics, 14(12): L379-L384.

Griffin, W.L., O'Reilly, S.Y. and Ryan, C.G., 1999. The composition and origin of subcontinental lithospheric mantle. In: Y. Fei, C.M. Bertka and B.O. Mysen (Editors), Mantle Petrology: Field Observations and High Pressure Experimentation:Atribute to Francis R. (Joe) Boyd. Special Publication. The Geochemical Society, Houston, pp. 13-45.

Harris, J.W., 1987. Recent physical, chemical, and isotopic research of diamonds. In: P.H. Nixon (Editor), Mantle Xenoliths. John Wiley and Sons.

Hood, C. and McCandless, T., 2003. Systematic variations in xenocryst mineral composition at the province scale, Buffalo Hills kimberlites, Alberta, Canada, 8th International Kimberlite Conference, Victoria (BC), Canada, pp. 3 p (CD).

Janse, A.J.A., 1994. Is Clifford's rule still valid? Affirmative examples from around the world. In: H.O.A. Meyer and O.H. Leonardos (Editors), Diamonds: Characterization, Genesis and Exploration. CPRM - Special Publication Jan/94, Brasilia, pp. 215-235.

Kirkley, M.B., Gurney, J.J., Otter, M.L., Hill, S.J. and Daniels, L.R., 1991. The Application of C Isotope Measurements to the Identification of the Sources of C in Diamonds - a Review. Applied Geochemistry, 6(5): 477-494.

Leahy, K. and Taylor, W.R., 1997. The influence of the Glennie domain deep structure on the diamonds in Saskatchewan kimberlites. Geologiya I Geofizika, 38(2): 451-460.

Nimis, P. and Taylor, W.R., 2000. Single clinopyroxene thermobarometry for garnet peridotites. Part I. Calibration and testing of a Cr-in-Cpx barometer and an enstatite-in-Cpx thermometer. Contributions to Mineralogy and Petrology, 139(5): 541-554.

Ramsay, R.R., 1992. Geochemistry of Diamond Indicator Minerals. $\mathrm{PhD}$ Thesis, University of Western Australia, Perth.

Read, G. et al., 2004. Stratigraphic relations, kimberlite emplacement and lithospheric thermal evolution, Quiricó Basin, Minas Gerais State, Brazil. Lithos, 77(1-4): 803-818.

Stachel, T., 2007. Diamond. Mineralogical Association of Canada Short Course Series, 37: 1-22.

Tassinari, C.C.G. and Macambira, M.J.B., 1999. Geochronological provinces of the Amazonian Craton. Episodes, 22: 174-182.

Taylor, W.R., Jaques, A.L. and Ridd, M., 1990. Nitrogen-defect aggregation characteristics of some Australasian diamonds; timetemperature constraints on the source regions of pipe and alluvial diamonds. American Mineralogist, 75(11-12): 1290-1310.

Zurowski, 2003. Review of the Pimenta Bueno Diamond Exploration Project, Rondonia , Brazil for Santa Elina Mines Corporation. 